\title{
11. K-Ar DATING OF SAMPLES FROM SITES 782 AND 786 (LEG 125): THE IZU-BONIN FOREARC REGION ${ }^{1}$
}

\author{
John G. Mitchell, ${ }^{2}$ David W. Peate, ${ }^{3}$ Bramley J. Murton, ${ }^{3,4}$ Julian A. Pearce, ${ }^{3}$ Richard J. Arculus, ${ }^{5}$ and Sieger R. van der Laan ${ }^{6}$
}

\begin{abstract}
K-Ar whole-rock ages have been obtained for 30 samples from Sites 782 and 786, Ocean Drilling Program Leg 125 in the Izu-Bonin (Ogasawara) forearc region. They form a trimodal spread of ages between $9 \mathrm{Ma}$ and $44 \mathrm{Ma}$ and are, with a few exceptions, consistent with the inferred lithostratigraphy. The ages have been interpreted in terms of at least two distinct episodes of magmatic and/or hydrothermal activity. A group of ten samples, including the lava flows, gave an isochron age of $41.3 \pm 0.5$ $\mathrm{Ma}$ (middle-late Eocene). This is thought to represent the age of the principal magmatic development of the volcanic forearc basement, and is comparable to published ages on equivalent rocks from other parts of the forearc basement high (e.g., the Ogasawara Islands). It may be significant that this age is slightly younger than the timing of major plate reorganization in the Western Pacific at about $43 \mathrm{Ma}$. This was followed by a minor episode of intrusive magmatism at $34.6 \pm 0.7 \mathrm{Ma}$ (early Oligocene) which appears to have reset the ages of some of the earlier units. This event probably corresponds to the initiation of rifting of the "proto-arc" to form the Parece Vela Basin. Boninitic samples were erupted during both episodes of magmatism, the earlier being of low-Ca boninite type and the later being of medium- and high-Ca types. It is also possible that a third episode of intrusive magmatism affected the Izu-Bonin forearc region at both Sites 782 and 786 at about $17 \mathrm{Ma}$. This would be consistent with magmatic activity elsewhere in the region during the Miocene, associated with the end of active spreading in the Parece Vela Basin and the start of arc activity in the West Mariana Ridge.
\end{abstract}

\section{INTRODUCTION}

Before Ocean Drilling Program (ODP) Leg 125, the only detailed information about the basement of the Izu-Bonin forearc came from studies of the Ogasawara Islands, where the outer-arc or forearc basement high (see Honza and Tamaki, 1985) is exposed above sea level. These islands consist predominantly of an Eocene volcanic basement overlain by interbedded tuffs and limestones of EoceneOligocene age (e.g., Tsunakawa, 1983; Dobson, 1986). This basement is mainly made up of pillow lavas, hyaloclastites, volcanic breccias, and dikes belonging to the boninite and island-arc tholeiite magma series. During Leg 125, two sites (Site 782 and Site 786) were drilled into the forearc basement high to the north of the Ogasawara Islands (Fig. 1).

Site 782 lies about $275 \mathrm{~km}$ north of Chichijima in the Ogasawara Islands (Fig. 1). Forearc basement material was recovered at this site, although drilling only managed to penetrate about $70 \mathrm{~m}$ into the volcanic basement. Recovery was very poor and consisted of angular to subrounded clasts (possibly including pillow fragments) of andesite and dacite-rhyolite composition (see Shipboard Scientific Party, 1990a).

Site 786 is located about $75 \mathrm{~km}$ north of Site 782 (Fig. 1). The stratigraphy of Site 786 (a composite of Holes 786A and 786B) is summarized in Figure 2, together with the locations of samples chosen for dating. A major achievement of the Leg 125 drilling program was the drilling of Hole 786B, which penetrated more than $650 \mathrm{~m}$ of massive, brecciated, and pillowed lavas and dikes of an Eocene volcanic edifice (see Shipboard Scientific Party, 1990b). This drill

${ }^{1}$ Fryer, P., Pearce, J. A., Stokking, L. B., et al., 1992. Proc. ODP, Sci. Results, 125: College Station, TX (Ocean Drilling Program).

Department of Physics, University of Newcastle upon Tyne, Newcastle upon Tyne, NE1 7RU, United Kingdom.

${ }^{3}$ Department of Geological Sciences, University of Durham, Durham, DH1 3LE, United Kingdom.

${ }^{4}$ Institute of Oceanographic Sciences, Wormley, Godalming, Surrey, GU8 5UB, United Kingdom.

${ }^{5}$ Department of Geology and Geophysics, University of New England, Armidale, N.S.W. 2351, Australia.

${ }^{6}$ Hawaii Institute of Geophysics, University of Hawaii at Manoa, Honolulu. Hawaii 96822, U.S.A. hole provided a record of the construction and structure of the forearc basement and a rare opportunity to look at the tectonic and volcanic activity that marked the initiation of subduction. The upper part of the volcanic sequence at Hole 786B is made up of welded ash flows and massive and brecciated lavas with interbedded clastic sediments. Deeper levels are dominated by pillowed and massive lavas cut by a number of intrusive dikes and sills, some of which form sheeted units. Compositionally, the rocks span a wide range in $\mathrm{SiO}_{2}$ contents, from basalt to rhyolite, and about half of the sequence constitutes boninites and bronzite-andesites. Arculus et al. (this volume) identified eight major compositional groups within the igneous rocks, based on petrological and geochemical characteristics, and this classification will be followed in this study. Close examination of the complex lithostratigraphy of Hole 786B, taking into account cross-cutting dike relationships, has also enabled Arculus et al. (this volume) to develop a broad chronology of eruption and dike/sill intrusion. It is important to emphasize, however, that several factors made the unravelling of the temporal relationships between the various units somewhat problematical. Overall core recovery was poor, and the contacts between different lithological units were often not seen, which rather clouded the important distinction between dikes and lava flows. However, according to this model, the lithostratigraphical units encountered in Hole 786B, in order of formation, are:

1. Low-Ca bronzite-andesite dikes and low-Ca boninite pillow lavas.

2. Intermediate-Ca bronzite-andesite dikes, lavas and breccias, intermediate-Ca boninite breccias, and andesite, dacite and rhyolite lavas, breccias and dikes.

3. High-Ca boninite dikes or sills and intermediate-Ca boninite dikes and breccias.

Rocks recovered from the volcanic basement at Sites 782 and 786 show extensive evidence of alteration and vesicle infilling with few fresh rocks or glasses, and the metamorphic grade reaches upper greenschist facies (albite-chlorite-epidote-quartz assémblage) at the base of Hole 786B. The K-Ar technique has been used to date selected samples from these lithological units in an attempt to verify and quantify their inferred sequential relationships and thus place some 
A

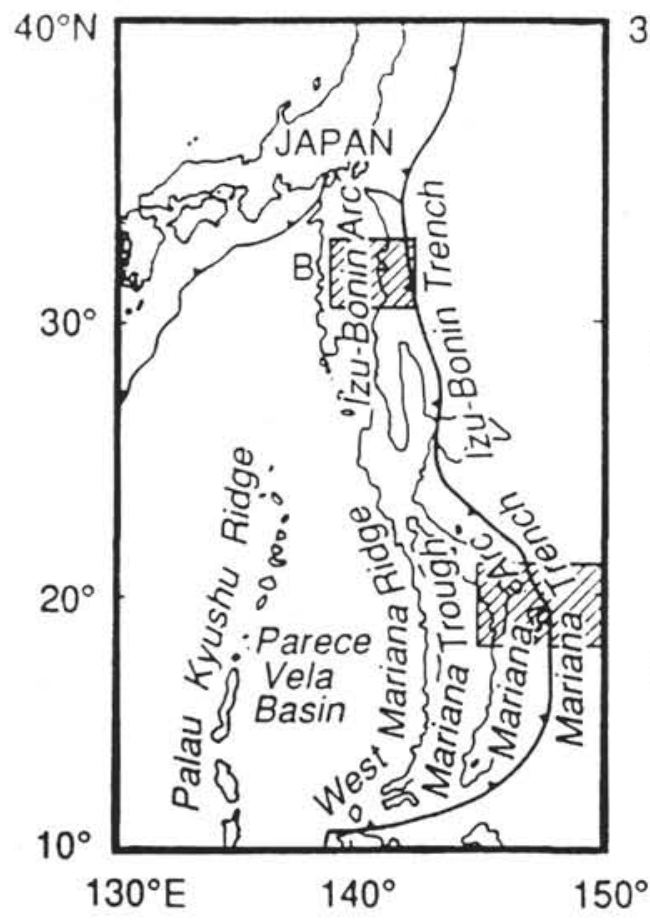

$\mathrm{B}$

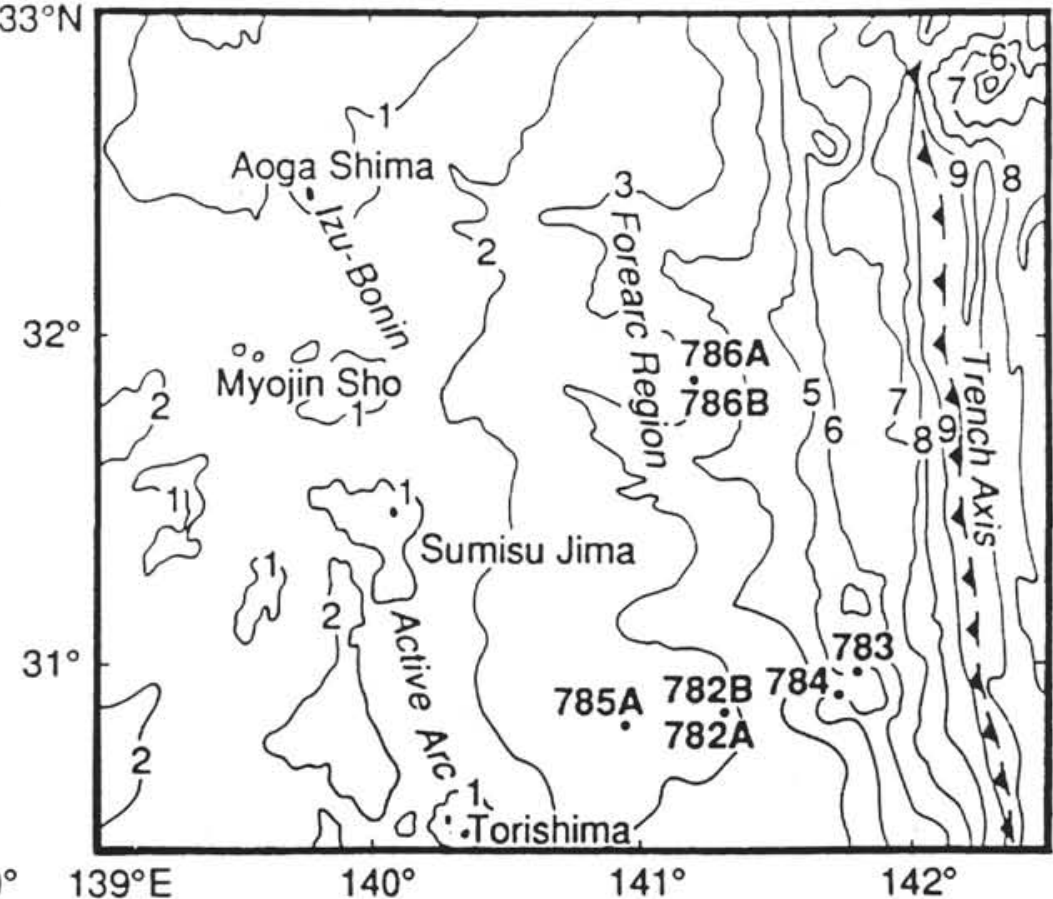

Figure 1. Location of Sites 782 and 786 showing (A) the two areas studied by the JOIDES Resolution in the Mariana-Izu-Bonin (Ogasawara) region and (B) the detailed setting of Sites 782 and 786 within the northern Izu-Bonin forearc terrane. Bathymetric contours are in kilometers below sea level.

temporal constraints on the magmatic development of the Izu-Bonin forearc in the region of Sites 782 and 786.

\section{EXPERIMENTAL METHODS}

Conventional whole-rock $\mathrm{K}$-Ar ages were determined by the methods described by Mitchell (1972) using a Kratos MS10 mass spectrometer coupled to a ultra-high vacuum gas extraction line. Isotope dilution analyses were performed by means of a ${ }^{38} \mathrm{Ar}$ "spike" calibrated against standard micas P-207 and B3203 (Lanphere and Dalrymple, 1965). Typical sample weights for $\mathrm{Ar}$ analysis were 300-mg aliquots. $\mathrm{K}$ was determined using a Corning EEL 450 flame photometer with lithium internal standard. Results, including error limits, are shown in Table 1. The quoted values are the mean of two Ar analyses, and the reported errors take into account both random effects (discrepancies between duplicates) and systematic effects (from spike calibration).

A total of 30 representative samples were selected for analysis from the various lithostratigraphic units. Virtually every sample examined exhibited some degree of alteration, especially of the groundmass phases, ranging from devitrification of the glassy phase to complete replacement of the primary silicates by combinations of chlorite, sericite, clay minerals, and carbonates. Experience with dating of mid-ocean ridge basalts has shown that the palagonite-smectite phase of alteration is generally closely associated in time with the crystallization and cooling of the lava flow or intrusive body (e.g., Staudigel et al., 1981), and that the higher K content of the altered rocks leads to lower errors. Therefore, samples were chosen for dating on the basis of an absence of evidence for more than one episode of alteration or vesicle infilling. The assumption implicit in this sampling methodology is that alteration is related to the same heat source as the magmatism and thus that alteration and magmatism are broadly contemporaneous.
Brief petrographic descriptions of most of the samples studied, including a qualitative assessment of their state of alteration, are given in the Appendix to this paper. The remainder can be found in van der Laan et al. (this volume).

\section{DISCUSSION OF RESULTS}

\section{Significance of the K-Ar Ages}

From Table 1, one can see that the samples show a range in calculated K-Ar ages from $9 \mathrm{Ma}$ to $44 \mathrm{Ma}$, although they tend to fall into three main clusters: one group at about $38 \mathrm{Ma}$ to $44 \mathrm{Ma}$ and a younger group at about $34 \mathrm{Ma}$ to $36 \mathrm{Ma}$, with nine samples giving the noticeably younger ages of $9 \mathrm{Ma}$ to $26 \mathrm{Ma}$. However, in view of the petrographic evidence for geochemical disturbance of $\mathrm{K}$ and, by implication, of the radiogenic Ar contents of the various rock types, it is not immediately obvious whether these dates do represent two, possibly three, magmatic and/or hydrothermal episodes.

Samples with approximately the same calculated age show a wide range of $\mathrm{K}_{2} \mathrm{O}$ contents. This suggests that $\mathrm{K}$ exchange has taken place, presumably concomitant with the alteration, and that there has been closed system behavior afterwards. However, although the effect of $\mathrm{K}$ addition is to reduce calculated $\mathrm{K}-\mathrm{Ar}$ ages, the observed younger ages are unlikely to have resulted from such a process because whole-rock $\mathrm{K}_{2} \mathrm{O}$ contents do not correlate significantly with the measured age.

To investigate further the significance of the three groups of ages, the data have been plotted on a ${ }^{40} \mathrm{Ar} *$ (radiogenic ${ }^{40} \mathrm{Ar}$ ) vs. $\mathrm{K}_{2} \mathrm{O}$ correlation diagram (Fig. 3). The systematics of this type of diagram have been discussed by Mitchell and Ineson (1988). They have argued that, if ${ }^{40} \mathrm{Ar}^{*}$ and $\mathrm{K}$ are linearly correlated for a suite of samples as a consequence of a single episode of potassium and argon exchange, then any age calculated from the gradient of the data array will have no immediate geological significance, except in the specific case 
Table 1. Conventional K-Ar data for samples from Sites 782 and 786, Izu-Bonin (Ogasawara) forearc region.

\begin{tabular}{|c|c|c|c|c|c|c|}
\hline $\begin{array}{l}\text { Core, section, } \\
\text { interval }(\mathrm{cm})\end{array}$ & $\begin{array}{l}\mathrm{K}_{2} \mathrm{O} \\
\text { (wt\%) }\end{array}$ & $\begin{array}{c}{ }^{40} \mathrm{Ar}^{*} \\
\left(10^{-4} \mathrm{~mm}^{3} \mathrm{~g}^{-1}\right)\end{array}$ & $\begin{array}{l}\text { Atmospheric } \\
\text { content }(\%)\end{array}$ & $\begin{array}{c}\text { Age } \\
(\mathrm{Ma} \pm 1 \sigma)\end{array}$ & $\begin{array}{c}\text { Unit } \\
\text { morphology }\end{array}$ & $\begin{array}{c}\text { Chemical } \\
\text { group }\end{array}$ \\
\hline \multicolumn{7}{|l|}{$125-782 \mathrm{~A}-$} \\
\hline $45 \mathrm{X}-1,31-35$ & $1.442 \pm 0.006$ & $8.47 \pm 0.27$ & 81.6 & $18.1 \pm 0.6$ & Clast & D \\
\hline $50 \mathrm{X}-1,19-30$ & $0.749 \pm 0.026$ & $7.47 \pm 0.18$ & 73.5 & $30.7 \pm 1.3$ & Clast & A \\
\hline \multicolumn{7}{|l|}{$125-782 \mathrm{~B}-$} \\
\hline $1 \mathrm{~W}-1,52-55$ & $0.899 \pm 0.019$ & $10.6 \pm 0.22$ & 46.1 & $36.2 \pm 1.1$ & Clast & A \\
\hline \multicolumn{7}{|l|}{$125-786 \mathrm{~A}-$} \\
\hline $12 X-1,133-138$ & $2.19 \pm 0.015$ & $6.55 \pm 0.26$ & 72.5 & $9.2 \pm 0.4$ & Clast & HiAlBas \\
\hline $16 X-1,24-29$ & $0.376 \pm 0.008$ & $1.87 \pm 0.12$ & 94.9 & $15.3 \pm 1.0$ & Clast & ICB \\
\hline \multicolumn{7}{|l|}{ 125-786B- } \\
\hline $2 \mathrm{R}-1,72-76$ & $0.480 \pm 0.007$ & $6.42 \pm 0.14$ & 45.0 & $41.0 \pm 1.1$ & Flow & ICBzA \\
\hline $6 \mathrm{R}-2,135-137$ & $0.278 \pm 0.002$ & $1.56 \pm 0.08$ & 90.6 & $17.3 \pm 0.9$ & Dike & HCB \\
\hline $8 \mathrm{R}-1,50-55$ & $0.877 \pm 0.020$ & $2.60 \pm 0.08$ & 73.6 & $9.2 \pm 0.4$ & Breccia & A \\
\hline $11 \mathrm{R}-1,121-123$ & $0.404 \pm 0.014$ & $3.38 \pm 0.10$ & 80.1 & $25.7 \pm 1.2$ & Breccia & ICB \\
\hline $16 \mathrm{R}-1,135-138$ & $0.708 \pm 0.005$ & $7.77 \pm 0.12$ & 46.8 & $33.7 \pm 0.6$ & Breccia & A \\
\hline $20 \mathrm{R}-1,43-46$ & $0.321 \pm 0.004$ & $1.25 \pm 0.18$ & 97.1 & $12.0 \pm 1.7$ & Dike & ICB \\
\hline $20 \mathrm{R}-1,124-128$ & $0.450 \pm 0.010$ & $4.95 \pm 0.14$ & 76.0 & $33.8 \pm 1.2$ & Flow & A \\
\hline $21 \mathrm{R}-1,20-28$ & $0.777 \pm 0.002$ & $4.21 \pm 0.09$ & 71.7 & $16.7 \pm 0.4$ & Flow & A \\
\hline $21 R-2,85-94$ & $0.180 \pm 0.008$ & $1.98 \pm 0.19$ & 94.5 & $33.8 \pm 3.6$ & Dike & HCB \\
\hline $30 \mathrm{R}-1,0-7$ & $0.636 \pm 0.008$ & $8.26 \pm 0.24$ & 78.9 & $39.8 \pm 1.3$ & Flow & ICBzA \\
\hline $30 \mathrm{R}-2,59-66$ & $0.644 \pm 0.009$ & $7.96 \pm 0.17$ & 77.7 & $37.9 \pm 1.0$ & Flow & ICBzA \\
\hline $32 \mathrm{R}-2,83-85$ & $1.483 \pm 0.022$ & $19.9 \pm 0.5$ & 79.5 & $41.1 \pm 1.2$ & Flow & $\mathrm{R}$ \\
\hline $34 \mathrm{R}-3,48-54$ & $0.614 \pm 0.007$ & $6.80 \pm 0.18$ & 73.8 & $34.0 \pm 1.0$ & Dike & HCB \\
\hline $35 \mathrm{R}-1,122-126$ & $1.22 \pm 0.03$ & $15.2 \pm 0.3$ & 83.1 & $38.2 \pm 1.2$ & Flow & $\mathrm{D}$ \\
\hline $40 \mathrm{R}-2,83-90$ & $0.293 \pm 0.003$ & $3.39 \pm 0.28$ & 95.2 & $35.5 \pm 3.0$ & Dike & $\mathrm{HCB}$ \\
\hline $51 R-1,75-79$ & $0.440 \pm 0.003$ & $4.81 \pm 0.08$ & 73.6 & $33.6 \pm 0.6$ & Breccia & ICB \\
\hline $57 \mathrm{R}-2,122-125$ & $0.798 \pm 0.003$ & $8.80 \pm 0.48$ & 91.4 & $34.2 \pm 1.9$ & Pillow & LCB \\
\hline $57 \mathrm{R}-4,7-13$ & $0.202 \pm 0.006$ & $2.53 \pm 0.13$ & 91.3 & $38.4 \pm 2.3$ & Pillow & LCB \\
\hline $58 \mathrm{R}-1,121-126$ & $0.076 \pm 0.007$ & $0.835 \pm 0.185$ & 98.7 & $33.7 \pm 8.1$ & Pillow & LCB \\
\hline $65 \mathrm{R}-1,25-32$ & $0.929 \pm 0.002$ & $10.91 \pm 0.18$ & 40.0 & $36.0 \pm 0.6$ & Dike & A \\
\hline $66 \mathrm{R}-2,128-135$ & $3.35 \pm 0.05$ & $45.2 \pm 0.6$ & 43.5 & $41.3 \pm 0.8$ & Dike & $\mathrm{R}$ \\
\hline $67 \mathrm{R}-1,56-59$ & $0.175 \pm 0.001$ & $2.35 \pm 0.11$ & 89.1 & $41.1 \pm 1.9$ & Dike & ICB \\
\hline $70 \mathrm{R}-1,92-97$ & $0.890 \pm 0.010$ & $11.2 \pm 0.2$ & 43.7 & $38.7 \pm 0.8$ & Dike & LCBzA \\
\hline $70 R-4,27-35$ & $0.180 \pm 0.008$ & $2.58 \pm 0.08$ & 71.7 & $43.9 \pm 2.4$ & Dike & $\mathrm{LCBzA}$ \\
\hline $72 R-1,3-7$ & $0.979 \pm 0.017$ & $10.8 \pm 0.2$ & 61.8 & $33.8 \pm 0.8$ & Dike & ICB \\
\hline
\end{tabular}

Notes: Ages calculated using: $\lambda_{\mathrm{c}}=0.581 \times 10^{-10} \mathrm{a}^{-1}, \lambda_{\mathrm{b}}=4.962 \times 10^{-10} \mathrm{a}^{-1},{ }^{40} \mathrm{~K} / \mathrm{K}=0.01167$ atom percent (from Steiger and Jäger, 1977). For explanation of chemical groups, see Arculus et al. (this volume): $R=$ rhyolite, $D=$ dacite, $A=$ andesite, $\mathrm{HCB}=$ high-Ca boninite, $\mathrm{ICB}=$ intermediate-Ca boninite, ICBzA = intermediate-Ca bronzite-andesite, $\mathrm{LCB}=1$ low-Ca boninite, $\mathrm{LCBZA}=$ low-Ca bronzite-andesite, $\mathrm{HiAlBas}=$ high-Al basalt.

where the intercept is zero. In this case, the age calculated using the standard "isochron" equation will represent the time of closure of the system, either when the samples crystallized or when the system had been totally reset. If the intercept is non-zero, then this implies that the system had only been partially reset.

The samples from Hole 786B, illustrated on Figure 3, have been divided into groups according to lithology (main volcanic edifice vs. late-stage intrusive) and measured $\mathrm{K}$ - $\mathrm{Ar}$ age ( 38 to $44 \mathrm{Ma}, 33$ to 36 $\mathrm{Ma}$, or $<30 \mathrm{Ma}$ ). A separate least-squares regression line has been fitted to the samples of each of the two main age groups. The first group comprises the ten samples with $\mathrm{K}$-Ar ages between $38 \mathrm{Ma}$ and $44 \mathrm{Ma}$, which are all from the lithostratigraphic units inferred to have been involved in the principal magmatic development of the IzuBonin forearc basement. The second group consists of the ten samples with $\mathrm{K}-\mathrm{Ar}$ ages between $33 \mathrm{Ma}$ and $36 \mathrm{Ma}$. Six of these samples are clearly late-stage high-Ca boninite or andesite dikes, but four are from chemical groups or lithologic units which were expected to have been associated with the first group of samples and these will be discussed further below. For both of these groups, the conventional K-Ar ages of the samples are concordant at the $2 \sigma$ confidence level and give average ages of $40.1 \pm 1.8 \mathrm{Ma}$ and $34.2 \pm 0.8 \mathrm{Ma}$ respectively. The data for each group conform, at the $2 \sigma$ confidence level, to the "ideal" "zero-intercept" situation. The gradient of the fitted regression line yields an isochron age of $41.3 \pm 0.5 \mathrm{Ma}$ (on ten samples) for the older group of samples. For the younger suite of samples, using all ten samples gives an age of $34.6 \pm 0.7 \mathrm{Ma}$. If the four samples (125-786B20R-1, 124-128 cm; 125-786B-51R-1, 75-59 cm; 125-786B-57R-2, $122-125 \mathrm{~cm}$; $125-786 \mathrm{~B}-58 \mathrm{R}-1,121-126 \mathrm{~cm})$, thought on stratigraphic and compositional grounds to be related to the earlier event, are excluded from the regression line, the remaining six samples still give an isochron age of $34.8 \pm 1.0 \mathrm{Ma}$. The preferred interpretation of these results is for two distinct magmatic (and associated hydrothermal) events: one at about $41 \mathrm{Ma}$, and a second event at about $35 \mathrm{Ma}$. In the case of the 41-Ma ages, the observed alteration within the analyzed samples is inferred to have taken place almost contemporaneously with emplacement and crystallization of the magmatic units, but the event at $35 \mathrm{Ma}$ is more complex and will be discussed in more detail below.

The significance of the youngest group of ages, which includes the various clasts sampled from Holes 786A, 782A, and 782B, is less clear, especially as they span a wide age range of $9 \mathrm{Ma}$ to $26 \mathrm{Ma}$. They form a rather scattered distribution on Figure 3. A least-squares regression line (not illustrated) produces a non-zero intercept and thus the $\mathrm{K}-\mathrm{Ar}$ ages obtained are not of any immediate geological significance as it can not be determined with any certainty whether the $\mathrm{K}$ and $\mathrm{Ar}$ distribution within these samples have been disturbed. 

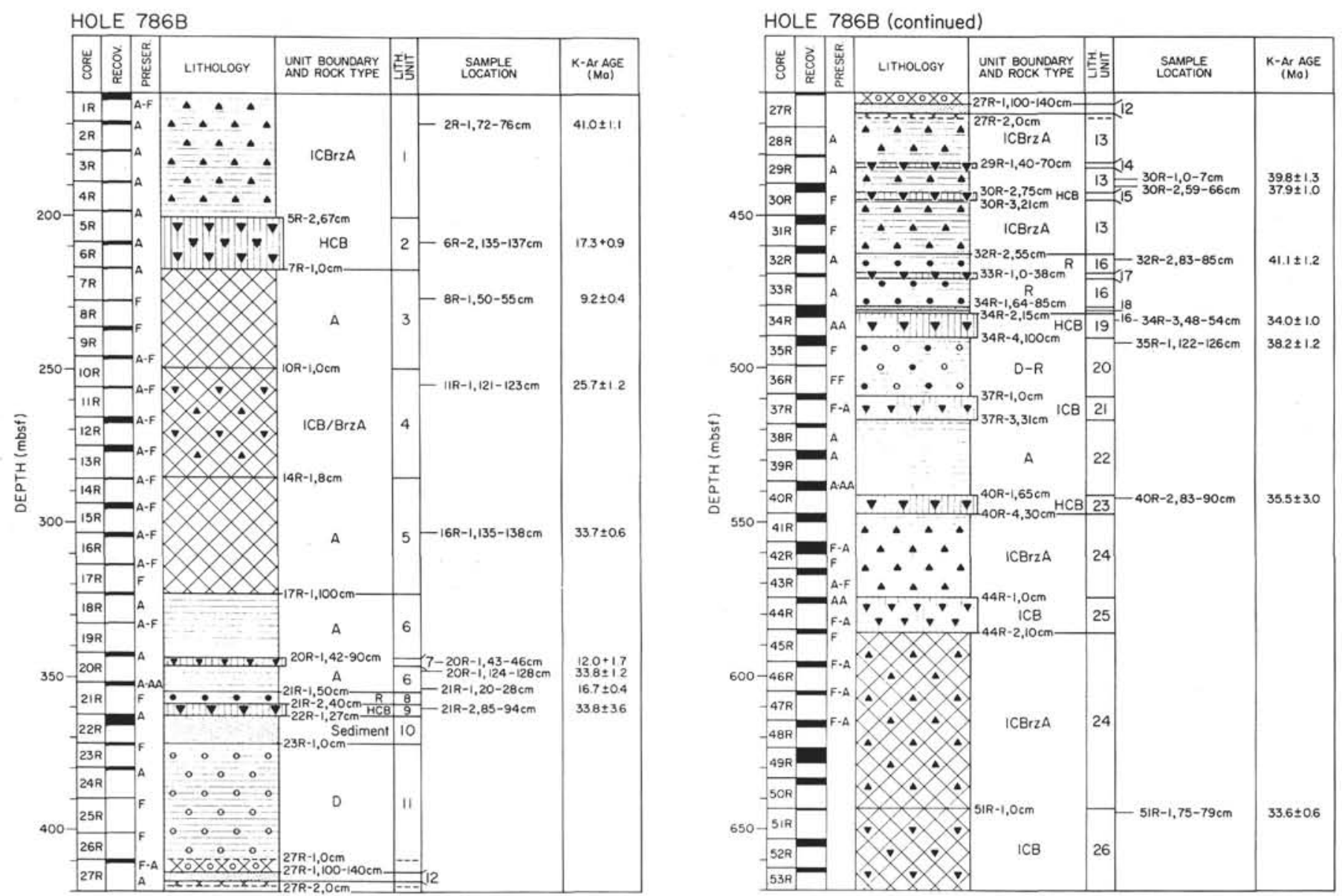

Figure 2. Stratigraphic section of Site 786 (Arculus et al., this volume) showing the positions of samples chosen for K-Ar dating.

However, the possibility of a genuinely younger episode (or episodes) of dike activity cannot be ruled out and would be consistent with magmatism occurring elsewhere in the region at this time (Sharaskin et al., 1981; Hickey-Vargas and Reagan, 1987). The fact that several samples, compositionally akin to the magmas emplaced at both 41 $\mathrm{Ma}$ and $35 \mathrm{Ma}$, produce anomalous young ages less than $30 \mathrm{Ma}$ would suggest that some event has occurred relatively recently in order to perturb their K-Ar ages.

These separate episodes of magmatic and hydrothermal activity are now discussed in detail in the context of the lithostratigraphical units involved and their inferred spatial and temporal relationships (Arculus et al., this volume).

\section{Relationship Between K-Ar Ages and Lithostratigraphy}

The lithostratigraphic model of Arculus et al. (this volume) can be combined with the K-Ar data of this study, to develop a consistent model for the sequential development of the volcanic forearc basement at Site 786. The first stage was the formation of the basement sequence of low-Ca bronzite-andesite dikes, overlain by low-Ca boninite pillow lavas. The second stage was the formation of the upper sequence of flows and breccias of intermediate- $\mathrm{Ca}$ boninite, intermediate-Ca bronzite-andesite, andesite, dacite and rhyolite. Feeder dikes to this upper sequence are found intruding the underlying stratigraphy. Units of the first and second stages were all erupted or intruded at about $41 \mathrm{Ma}$ to form a major volcanic edifice. The whole sequence was occasionally cut by high-Ca boninite and intermediate$\mathrm{Ca}$ boninite dikes at about $35 \mathrm{Ma}$ and possibly also at $17 \mathrm{Ma}$.
Although most of the analyzed samples can be related to either of the two main events solely on the basis of their K-Ar ages, there are several examples where the measured $\mathrm{K}$-Ar age apparently conflicts with the lithostratigraphic unit assignments of Arculus et al. (this volume). For example, three samples that gave 35 -Ma ages (125786B-20R-1, 124-128 cm; 125-786B-51R-1, 75-79 cm; 125-786B$57 \mathrm{R}-2,122-125 \mathrm{~cm}$ ) came from units which, from stratigraphic and compositional considerations, were expected to belong to the older, 41-Ma magmatic episode. This conflict between measured K-Ar age and inferred stratigraphic position can be resolved if the $\mathrm{K}$ and $\mathrm{Ar}$ systematics of these units had been totally reset by the episode of intrusive magmatism at $35 \mathrm{Ma}$.

Samples from the basal intrusive complex (125-786B-66R-2, $128-135 \mathrm{~cm} ; 125-786 \mathrm{~B}-67 \mathrm{R}-1,56-59 \mathrm{~cm} ; 125-786 \mathrm{~B}-70 \mathrm{R}-1,92-97$ $\mathrm{cm}$; $125-786 \mathrm{~B}-70 \mathrm{R}-4,27-35 \mathrm{~cm})$ and the overlying lava flows (Samples 125-786B-2R-1, 72-76 cm; 125-786B-30R-1, 0-7 cm; 125-786B-30R-2, 59-66 cm; 125-786B-32R-2, 83-85 cm; $125-$ 786B-35R-1, 122-126 cm), which together form the main volcanic edifice, all gave $\mathrm{K}$-Ar ages of $39 \mathrm{Ma}$ to $43 \mathrm{Ma}$, with the few exceptions discussed separately below, and are thus taken to represent the earliest and principal phase of magmatic activity at Site 786 .

The $41.3 \pm 0.5 \mathrm{Ma}$ isochron age for the forearc basement at Site 786 is reasonably consistent with the paleontological evidence. The sediments immediately overlying the volcanic sequences at both Site 786 and Site 782 have been assigned to the middle Eocene nannofossil Zone $\mathrm{CP} 13 \mathrm{c}$ by $\mathrm{Xu}$ and Wise (this volume). According to the time scale of Berggren et al. (1985), this zone is dated at 44.4 Ma to 47.0 Ma. Milner (this volume), using the less well-preserved planktonic 


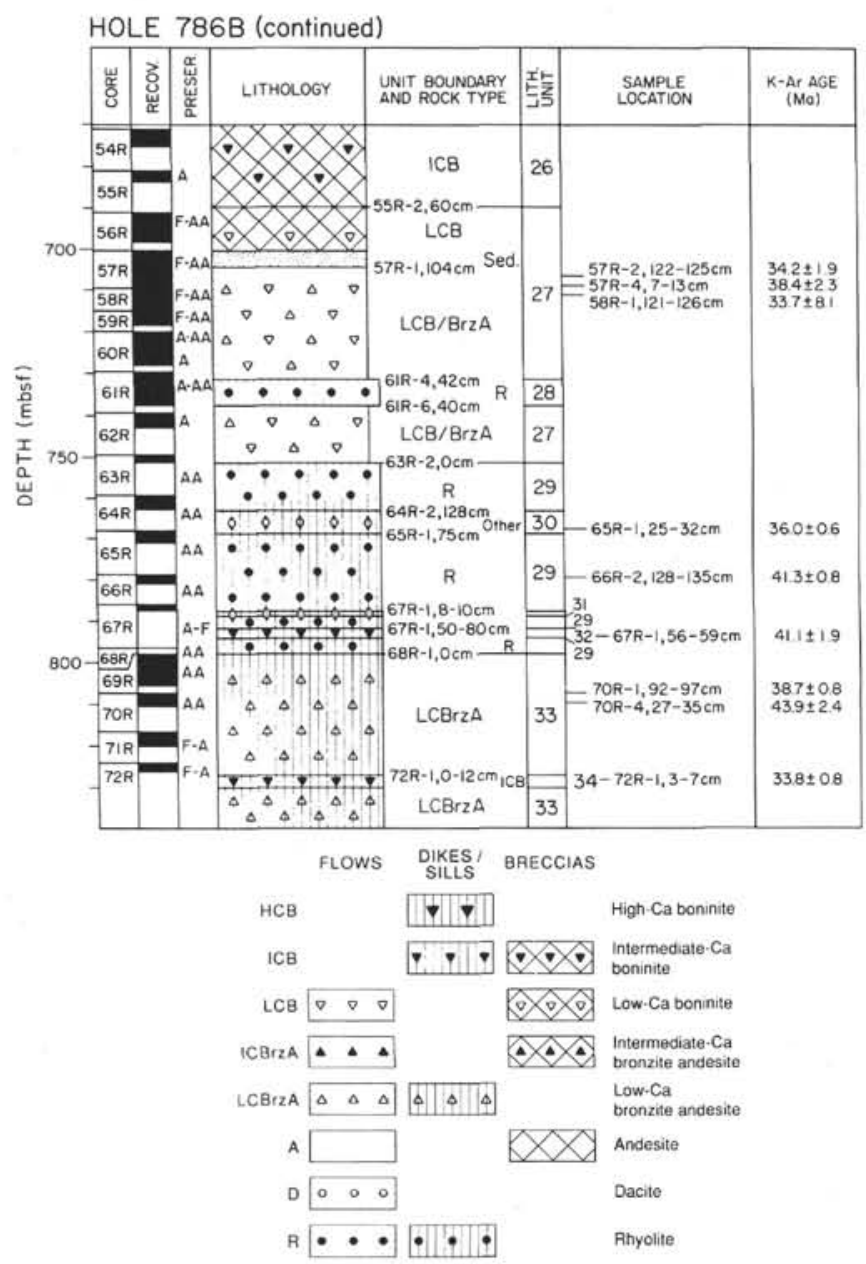

Figure 2 (continued).

foraminifers, placed the same sediments within the P10/P11 planktonic foraminifer zones (52 Ma to $45 \mathrm{Ma}$; Berggren et al., 1985). Microfossil determinations from sediments intercalated within the lavas in Hole 786B show that the sequence is predominantly of middle to late Eocene age ( $\mathrm{Xu}$ and Wise, this volume; Milner, this volume). The slight discrepancy between the radiometric K-Ar age $(41.3 \pm 0.5$ $\mathrm{Ma}$ ) of the volcanic basement and the inferred age of the microfossil assemblages (47 Ma to $45 \mathrm{Ma}$ ) from the immediately overlying sediments can be largely attributed to the old problem of absolute calibration of the geologic time scale, which for Eocene events could be 1 to 2 m.y. in error, and/or to the fact that the K-Ar age, being an alteration age, may slightly postdate the associated magmatic event.

The results obtained for samples from the low-Ca boninite pillow lava/hyaloclastite sequence between Sections $125-786 \mathrm{~B}-57 \mathrm{R}-1$ to $-63 R-1$ proved to be more problematic. Three samples have been dated from this part of the core, but one (125-786B-58R-1, 121-126 $\mathrm{cm}$ ) has a high error resulting from a high percentage of atmospheric $\mathrm{Ar}$ and is thus of little statistical significance. Of the other two, one sample gives an older age (125-786B-57R-4, 7-13 cm; $38.4 \pm 2.3$ $\mathrm{Ma}$ ), which would be consistent with its inferred stratigraphic position as part of the early volcanic edifice, whereas the other gives a clearly younger age (Sample 125-786B-57R-2, $122-125 \mathrm{~cm} ; 34.2 \pm 1.9 \mathrm{Ma}$ ). It seems reasonable to assume that the age of this sample has been totally reset as a result of hydrothermal activity associated with one of the younger ( $35 \mathrm{Ma}$ ) generation of intrusives nearby.

Four samples (125-786B-8R-1, 50-55 cm, $9 \mathrm{Ma} ; 125-786 \mathrm{~B}-20 \mathrm{R}-1$, 124-128 cm; 125-786B-21R-1, 20-28 cm, $17 \mathrm{Ma} ; 125-786 \mathrm{~B}-51 \mathrm{R}-1$, $75-79 \mathrm{~cm}, 34 \mathrm{Ma}$ ) belonging to the lava flow and brecciated flow sequences overlying the pillow lavas have been dated at less than $40 \mathrm{Ma}$. This is despite their strong compositional similarities, notably in terms of Nd isotopes (see Pearce et al., this volume), to the older 41-Ma lithologies. These samples have anomalously high $\mathrm{P}$ and $\mathrm{Y}$ contents and this style of enrichment has been attributed (Taylor et al., in press) to the alteration of volcanic glass to smectite. Furthermore, the sediments immediately overlying the volcanic sequence at Site 786 have been dated as middle Eocene from their nannofossil assemblages ( $\mathrm{Xu}$ and Wise, this volume), which therefore constrains all extrusive magmatism to be older than about $44 \mathrm{Ma}$ (Berggren et al., 1985). Thus it seems likely that they were erupted as part of the 41-Ma magmatic episode and then underwent subsequent alteration, perhaps related to the $35-\mathrm{Ma}$ intrusions, which then only partially reset (or totally, in the case of Sample 125-786B-51R-1, 75-79 cm) their $\mathrm{K}$ and Ar systematics.

It is notable that samples, which from stratigraphic arguments were expected to give ages of $41.3 \pm 0.5 \mathrm{Ma}$ and in fact gave ages less than $37 \mathrm{Ma}$, are all found within the pillow lava/hyaloclastite or brecciated parts of the core. In these regions, the highly fractured nature of the units would have provided sufficient permeability for the extensive circulation of hydrothermal fluids driven by cooling of intrusive dikes or sills emplaced at $35 \mathrm{Ma}$ (or even younger), and thus allow a younger phase of alteration to almost completely overprint any effects associated with the initial emplacement and cooling of the magma. In contrast, the more massive morphology and lower permeability of the basal intrusive complex prevented any widespread fluid circulation and concomitant alteration associated with the younger phase of dike intrusion, and thus they have maintained their older ages.

Samples of the high-Ca boninite and intermediate-Ca boninite groups of dikes or sills consistently gave ages younger than $37 \mathrm{Ma}$, which is in keeping with their interpretation by Arculus et al. (this volume) as being later (post-volcanic) stages of magmatism in this region. Of these, six gave similar ages whose mean is $34.8 \pm 1.0 \mathrm{Ma}$ (Samples 125-786B-16R-1, 135-138 cm; 125-786B-21R-2, 85-94 cm; 125-786B-34R-3, 48-54 cm; 125-786B-40R-2, 83-90 cm; $125-$ 786B-65R-1, 25-32 cm; 125-786B-72R-1, 3-7 cm) and this has been interpreted as representing the age of intrusion.

Seven of the analyzed samples from Site 786 gave noticeably young ages of less than $30 \mathrm{Ma}$. These included high-Ca and intermediate-Ca boninite intrusions (Samples 125-786B-11R-1, 121-123 $\mathrm{cm}, 26 \mathrm{Ma} ; 125-786 \mathrm{~B}-20 \mathrm{R}-1,43-46 \mathrm{~cm}, 12 \mathrm{Ma}$ ) compositionally similar to the 35-Ma suite of dikes and clasts recovered from Hole 786A (Samples 125-786A-12X-1, 133-138 cm, 9 Ma; 125-786A$16 \mathrm{X}-1,24-29 \mathrm{~cm}, 15 \mathrm{Ma})$. The andesite units of Samples 125-786B$8 \mathrm{R}-1,50-55 \mathrm{~cm}$ (9 Ma) and 125-786B-21R-1, 20-28 cm (17 Ma), are thought to have been erupted during the 41-Ma episode of magmatism and were discussed earlier. The sill encountered at Sections $125-786 \mathrm{~B}-5 \mathrm{R}-2$ to $-6 \mathrm{R}-1$ (Unit IV.2) is compositionally distinct from the other late-stage intrusives because of its higher $\mathrm{TiO}_{2}$ content, and thus its 17-Ma age (Sample 125-786B-6R-2, 133-137 cm) may be significant. A 17-Ma reference isochron has been included on Figure 3. A magmatic episode at about $17 \mathrm{Ma}$ would be roughly coincident with the Umatac Formation volcanic episode on Guam in the Mariana arc (e.g., Hickey-Vargas and Reagan, 1987). Ages of less than $17 \mathrm{Ma}$ cannot be correct because these samples are part of the volcanic basement. There are no obvious magmatic events of this age in the forearc region, although a volcanic clast found at Hole $786 \mathrm{~A}$ in Section 125-786A-6X-5 in middle Miocene sediments (Shipboard Scientific Party, 1990b; 11 to 12 Ma; Berggren et al., 1985) may be a product of young magmatic activity and, if so, may have reset these ages.

Evidence for relatively recent injection of magma into an intraoceanic forearc terrane was obtained during Leg 125 at Site 781 , situated in the Mariana forearc, where a recent $(1.7 \mathrm{Ma})$ sill was encountered within the sediment pile (Marlow et al., this volume). Thus, it seems reasonable to speculate about the possibility of lateral emplacement of sills, of Miocene or younger age, into the sediments 


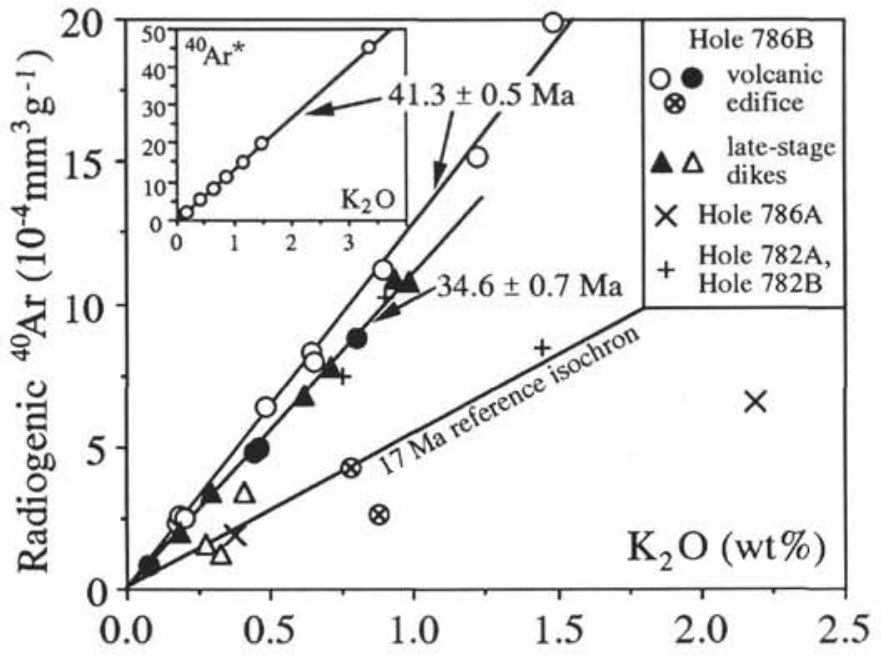

Figure 3. Radiogenic ${ }^{40} \mathrm{Ar}\left(10^{-4} \mathrm{~mm}^{3} \mathrm{~g}^{-1}\right)$ vs. $\mathrm{K}_{2} \mathrm{O}$ (wt\%) correlation diagram. Key to symbols: volcanic edifice ages: open circles $=38$ to $44 \mathrm{Ma}$; solid circles $=33$ to 36 Ma reset ages; circled crosses $=<30$ Ma reset; late-stage dikes: solid triangles $=33$ to $36 \mathrm{Ma}$; open triangles $=<30 \mathrm{Ma}$. Least-squares regression statistics: $41-\mathrm{Ma}$ isochron $(10$ samples; gradient $=13.49 \pm 0.17$; intercept $=$ $\left.-[3.3 \pm 2.2] \times 10^{-5} \mathrm{~mm}^{3} \mathrm{~g}^{-1}\right) ; 35$-Ma isochron ( 10 samples; gradient $=11.28$ \pm 0.23 ; intercept $=-[0.6 \pm 1.4] \times 10^{-5} \mathrm{~mm}^{3} \mathrm{~g}^{-1}$ ).

overlying the Izu-Bonin forearc basement. It is intriguing that at Site 786 , samples with the markedly younger ages are all apparently restricted to the upper $200 \mathrm{~m}$ of the igneous basement or as clasts within the overlying sediments. Fluid advection within the sediment pile and uppermost parts of the basement, associated with the emplacement and cooling of such Miocene or younger sills, could have been responsible for perturbing the $\mathrm{K}$-Ar ages of samples in this area.

\section{REGIONAL SIGNIFICANCE OF THE K-Ar AGES}

From these results, it is apparent that the bulk of the forearc basement at Site 786 was erupted or intruded at about $41 \mathrm{Ma}$ (close to the middle/late Eocene boundary; Berggren et al., 1985). This middle Eocene age may be compared with ages inferred for the surface outcrops of the Izu-Bonin forearc exposed at the Ogasawara Islands. On Chichijima and Hahajima, tuffaceous sediments intercalated with the volcanics contain foraminiferal assemblages that indicate a lower to middle Eocene age (Kodama et al., 1983). K-Ar ages of $39 \mathrm{Ma}$ to $43 \mathrm{Ma}$ (Upper Eocene) have been reported for boninitic and dacitic rocks on Chichijima (Tsunakawa, 1983) and for an andesite from Hahajima (Kaneoka et al., 1970), in good agreement with the isochron K-Ar age of $41.3 \pm 0.5 \mathrm{Ma}$ obtained at Site 786 in this study. In detail, the study of Chichijima by Tsunakawa (1983) contained four fresh samples that gave similar ages of $41 \pm 2 \mathrm{Ma}$. Most of the other samples yielded younger ages of $22 \mathrm{Ma}$ to $34 \mathrm{Ma}$, which were attributed to radiogenic $\mathrm{Ar}$ loss from alteration of the samples. However, three fresh (boninite pillow lavas), or only partially altered (dacite dike, rhyolite) samples, gave anomalously young ages of $5 \mathrm{Ma}$ to $10 \mathrm{Ma}$, and Tsunakawa (1983) argued either for a genuinely young eruption age for these samples or that some thermal disturbance at 5 Ma to $10 \mathrm{Ma}$ had reset their K-Ar ages (cf. Samples 125-786A-12X-1, $133-138 \mathrm{~cm}$, and $125-786 \mathrm{~B}-8 \mathrm{R}-1,50-55 \mathrm{~cm}$, of this study which also gave $\mathrm{K}$-Ar ages of about $9 \mathrm{Ma}$ ). Dobson (1986) has reported a ${ }^{40} \mathrm{Ar} /{ }^{39} \mathrm{Ar}$ age of $48.1 \pm 0.5 \mathrm{Ma}$ on a glass separate from a boninite pillow rim taken from the Marubewan Formation on Chichijima, which was corroborated by middle Eocene (43 $\mathrm{Ma}$ to $47 \mathrm{Ma}$ ) radiolarian faunas found in the interpillow sediments. However, it was noted that sample might contain excess radiogenic $\mathrm{Ar}$ and thus give a slightly older age for the boninitic volcanism.
The inferred 41.3 $\pm 0.5-\mathrm{Ma}$ age for the forearc basement at Site 786 has important implications for models of the initiation of subduction in the Western Pacific region (see discussion in Pearce et al, this volume). Most models assume that the boninite volcanism took place after the initiation of subduction of the Pacific Plate beneath the Philippine Sea Plate taken to have occurred at $43 \mathrm{Ma}$ as a consequence of a major change in absolute plate motion of the Pacific Plate (Clague and Dalrymple, 1987). Thus much hangs on the validity of the $48-\mathrm{Ma}$ date for Chichijima given by Dobson (1986) as this is the only age older than 43 Ma so far obtained for the Izu-Bonin forearc, and further work is required in order to verify whether some of the volcanism on Chichijima did indeed predate the plate reorganization.

The Eocene boninitic volcanic edifice and forearc basement at Site 786 was intruded by a series of dikes or sills of intermediate- and high-Ca boninite affinities which give $\mathrm{K}-\mathrm{Ar}$ ages of $34.8 \pm 1.0 \mathrm{Ma}$. Hydrothermal activity around these intrusive units apparently partially or completely reset the K-Ar systematics of several of the older lithostratigraphical units, notably the pillow lava/hyaloclastite sequence and the breccia horizons. Volcanic clasts recovered at Site 782 also gave $\mathrm{K}-\mathrm{Ar}$ ages of $31 \mathrm{Ma}$ to $36 \mathrm{Ma}$. This early Oligocene magmatic event can be linked to the rifting of the early arc to form the Parece Vela Basin and extension within the forearc basin (Sharaskin et al., 1981).

Several samples, including a clast from Site 782, which represent dikes or sills of boninitic, basaltic and andesitic affinities, produced $\mathrm{K}$-Ar ages of $9 \mathrm{Ma}$ to $17 \mathrm{Ma}$. If these Miocene ages are real, then this activity would be contemporaneous with the end of spreading in the Parece Vela Basin and the start of arc activity in the West Mariana Ridge (Sharaskin et al., 1981).

The triumvirate of ages proposed here for the magmatic activity at Site 786 in the Izu-Bonin forearc (41 Ma, $35 \mathrm{Ma}$, and possibly $17 \mathrm{Ma}$ is reminiscent of the timing of the main magmatic episodes dated on Guam in the southern Mariana Arc (e.g., Hickey-Vargas and Reagan, 1987): Facpi Formation, late-middle Eocene (44 Ma); Alutom Formation, late Eocene-early Oligocene (32 Ma to $36 \mathrm{Ma}$ ); and Umatac Formation, Miocene (14 Ma).

\section{SUMMARY}

In conclusion, the K-Ar results from Site 786 have indicated an age of $41.3 \pm 0.5 \mathrm{Ma}$ (middle-late Eocene) for the principal magmatic development of the volcanic basement, which thus is of similar age to other parts of the outer-arc high (the Ogasawara Islands). This confirms the implied Eocene age for the Izu-Bonin forearc volcanic basement, previously inferred from paleontological and $\mathrm{K}-\mathrm{Ar}$ evidence from the Ogasawara Islands. This was followed by a minor, later episode of intrusives at $34.6 \pm 0.7 \mathrm{Ma}$ (early Oligocene) and possibly also at about $17 \mathrm{Ma}$ (early Miocene).

The $\mathrm{K}-\mathrm{Ar}$ ages of the lithostratigraphic units are, in general, consistent with their inferred stratigraphic relationships. With just a few exceptions, the extrusive sequence and their intrusive chemical equivalents all produce older ages of about $41 \mathrm{Ma}$. Although the units comprising the younger, 35-Ma dike generation, form only a minor proportion of the overall magmatic sequence in Hole 786B, they apparently were effective in resetting the $\mathrm{K}-\mathrm{Ar}$ ages of particular levels within the older volcanic edifice, notably the pillow lava and breccia horizons. This is attributed to an enhanced development of hydrothermal systems around the younger dikes as a result of the greater permeability of these horizons.

\section{ACKNOWLEDGMENTS}

David Peate, Julian Pearce, and Bramley Murton acknowledge support from the Natural Environment Research Council (UK) through an Ocean Drilling Program Special Topics research grant (GR3/416). Reviews by Steve DeLong and Dave Rex were appreciated. 


\section{REFERENCES}

Berggren, W. A., Kent, D. V., Flynn, J. J., and Van Couvering, J. A., 1985. Cenozoic geochronology. Geol. Soc. Am. Bull., 96:1407-1418.

Clague, D. A., and Dalrymple, G. B., 1987. The Hawaiian-Emperor volcanic chain. Part I. Geologic evolution. In Decker, R. W., Wright, T. L., and Stauffer, P. H. (Eds.), Volcanism in Hawaii (Vol. 1), Geol. Surv. Prof. Pap. U.S., 1350:5-54.

Dobson, P. F., 1986. The petrogenesis of Boninite: a field, petrologic, and geochemical study of the volcanic rocks of Chichi-Jima, Bonin Islands, Japan [Ph.D. dissert.]. Stanford Univ., Stanford, CA.

Hickey-Vargas, R., and Reagan, M. K., 1987. Temporal variation of isotope and rare-earth element abundances in volcanic rocks from Guam: implications for the evolution of the Mariana Arc. Contrib. Mineral. Petrol. 97:497-508

Honza, E., and Tamaki, K., 1985. The Bonin Arc. In Nairn, A.E.M., Stehli, F. G., and Uyeda, S. (Eds.), The Ocean Basins and Margins (Vol. 7): New York (Plenum), 459-502.

Kaneoka, I., Isshiki, N., and Zashu, S., 1970. K-Ar ages of the Izu-Bonin Islands. Geochem. J., 4:53-60.

Kodama, K., Keating, B. H., and Helsley, C. E., 1983. Paleomagnetism of the Bonin Islands and its tectonic significance. Tectonophysics, 95:25-42.

Lanphere, M. A., and Dalrymple G. B., 1965. P-207: an interlaboratory standard muscovite for argon and potassium analysis. J. Geophys. Res. 10:3947-3949.

Mitchell, J. G., 1972. Potassium argon ages from the Cheviot Hills, northern England. Geol. Mag., 109:421-426.

Mitchell, J. G., and Ineson P. R., 1988. Models of single-stage concomitant potassium-argon exchange: an interpretation of discordant whole rock $\mathrm{K}$-Ar data from hydrothermally altered igneous rocks of the South Pennine Orefield, U.K. Earth Planet. Sci. Lett., 88:69-81.

Sharaskin, A. Y., Bogdanov, N. A., and Zakariadze, G. S., 1981. Geochemistry and timing of marginal basin arc magmatism in the Philippine Sea. Philos. Trans. R. Soc. London A, 300:287-297.

Shipboard Scientific Party, 1990a. Site 782. In Fryer, P., Pearce, J. A., et al., Proc: ODP, Init. Repts., 125: College Station, TX (Ocean Drilling Program). 197-252.

1990b. Site 786. In Fryer, P., Pearce, J. A., et al., Proc. ODP, Init. Repts.. 125: College Station, TX (Ocean Drilling Program), 313-363.

Staudigel. H., Hart, S. R., and Richardson, S. H., 1981. Alteration of the oceanic crust: processes and timing. Earth Planet. Sci. Lett., 52:311-327.

Steiger, R. H., and Jäger, E., 1977. Subcommission on Geochronology: convention on the use of decay constants in geo-and cosmochronology. Earth Planet. Sci. Lett., 36:359-362.

Taylor, R. N., Lapierre, H., Vidal, P., Nesbitt, R. W., and Croudace, I. W., in press. Igneous geochemistry and petrogenesis of the Izu-Bonin forearc basin. In Taylor, B., Fujioka, K., et al., Proc. ODP, Sci. Results, 126 College Station, TX (Ocean Drilling Program).

Tsunakawa, H., 1983. K-Ar dating on volcanic rocks in the Bonin Islands and its tectonic implication. Tectonophysics, 95:221-232.

\section{Date of initial receipt: 1 October 1990}

Date of acceptance: 18 July 1991

Ms 125B-136

\section{APPENDIX}

\section{Brief Petrographic Descriptions}

\section{Sample 125-782A-}

50X-1, 19-30 cm: Moderately plagioclase-clinopyroxene phyric rock. Finegrained groundmass of plagioclase laths and equant spinel grains in a glassy matrix $(\sim 60 \%)$ replaced by pale to reddish brown amorphous clays. Vesicles ( 5\%) unfilled

\section{Sample 125-786A-}

$12 \mathrm{X}-1,133-138 \mathrm{~cm}$ : Moderately clinopyroxene-plagioclase phyric rock. Finegrained groundmass of plagioclase microlites and minor opaque grains in glassy matrix $(\sim 60 \%)$ strongly altered to pale orange-brown and dark olive-brown clays. Sample has abundant vesicles $(\sim 30 \%)$ occasionally filled with zeolite.
16X-1, 24-29 cm: Moderately orthopyroxene-clinopyroxene-plagioclase phyric rock, with large glomerocryst of highly-fractured orthopyroxene and smaller subhedral clinopyroxene. Fine-grained groundmass of plagioclase laths, with pale brown to green clay minerals variably replacing glass matrix $(\sim 70 \%)$. Vesicles $(\sim 20 \%)$ unfilled.

\section{Sample 125-786B-}

6R-2, 135-137 cm: Moderately olivine-clinopyroxene-orthopyroxene phyric rock, with euhedral olivine phenocrysts fully altered to brownish clays. Fine-grained groundmass of plagioclase microlites and prismatic clinopyroxene in glassy matrix $(\sim 50 \%)$ now completely replaced by brownish clay minerals. Vesicles $(\sim 10 \%)$ unfilled.

$8 \mathrm{R}-1,50-55 \mathrm{~cm}$ : Highly plagioclase-clinopyroxene rock. Fine-grained groundmass of plagioclase laths and minor spinel clots set in a glassy matrix $(\sim 60 \%)$ now totally altered to amorphous olive-green and brown clays. Vesicles $(\sim 10 \%)$ unfilled.

21R-1, 20-28 cm: Moderately plagioclase-clinopyroxene-(orthopyroxene) phyric rock. Fine-grained groundmass of plagioclase laths and tiny equant spinel grains in an altered glassy matrix ( $60 \%)$ of pale to dark brown clay minerals.

$21 \mathrm{R}-2,85-94 \mathrm{~cm}$ : Moderately orthopyroxene-clinopyroxene phyric rock, with orthopyroxene highly fractured and partially replaced by clays. Finegrained groundmass of plagioclase laths, equant clinopyroxene, and minor opaques. Interstitial glass $(\sim 50 \%)$ totally replaced by reddish-brown clay minerals. Calcite is found as thin veinlets and infilling occasional vesicles.

30R-1, 0-7 cm: Highly clinopyroxene-plagioclase-orthopyroxene phyric rock. Fine-grained groundmass of tiny plagioclase microlites and equant clinopyroxene. Interstitial glass almost totally replaced by olivegreen/orange-brown clay minerals. Vesicles $(\sim 10 \%)$ have greenish chloritic lining. Minor veinlet infilled with calcite and pale brown/green clays. Near veinlet, orthopyroxene phenocrysts extensively altered to green clays/chlorite.

$30 \mathrm{R}-2,59-66 \mathrm{~cm}$ : Moderately phyric rock, with glomerocrysts of plagioclaseclinopyroxene-spinel. Very fine-grained microcrystalline groundmass, dominated $(-80 \%)$ by altered glass now replaced by reddish brown clays and pale/blue green celadonite?, plus occasional plagioclase microlites and tiny abundant spinel grains. Calcite found in interstices in glomerocrysts.

34R-3, 48-54 cm: Moderately clinopyroxene-orthopyroxene phyric rock. Orthopyroxene completely pseudomorphed by an assemblage of calcite, amorphous brown/green clays, and chlorite. Fine-grained groundmass of equant clinopyroxene, often altered to chlorite and brown clays, and plagioclase laths. Interstitial glass matrix $(\sim 50 \%)$ replaced by pale redbrown clay minerals. Minor haematite is found, often associated with alteration of orthopyroxene phenocrysts. Irregular vesicles (15\%) infilled with calcite or brown/green clays and chlorite.

$35 \mathrm{R}-1,122-126 \mathrm{~cm}$ : Highly phyric rock with plagioclase and clinopyroxene phenocrysts often found together in glomerocrysts. Fine-grained groundmass of plagioclase microlites and tiny opaque grains set in a glassy matrix $(\sim 40 \%)$ almost totally altered to pale reddish-brown clays. Yellowgreen clays and blue-green celadonite (up to $15 \%$ ) found in interstitial spaces in glomerocrysts and groundmass and lining vesicles. Calcite found as infilling to abundant vesicles $(\sim 30 \%)$ and also in groundmass.

40R-2, 83-90 cm: Highly orthopyroxene phyric rock, with euhedral orthopyroxene completely replaced by a combination of pale/orange brown clays, haematite, and calcite. Fine-grained groundmass of plagioclase microlites, equant clinopyroxene, and minor opaques. Pale brown clays replaced glass matrix $(\sim 40 \%)$. Abundant interstitial calcite $(\sim 20 \%)$, also infilling occasional vesicles.

51 R-1, 75-79 cm: Highly plagioclase-clinopyroxene-orthopyroxene phyric rock. Plagioclase and clinopyroxene contain abundant glassy inclusions and commonly occur together in glomerocrysts. Orthopyroxene phenocrysts are partially altered to pale brown clays. Very fine-grained microcrystalline groundmass of plagioclase microlites, tiny pyroxenes, and minor spinel, with interstitial glass $(\sim 40 \%)$ mostly replaced by pale reddish-brown clays. Vesicles $(\sim 15 \%)$ unfilled.

$57 \mathrm{R}-2,122-125 \mathrm{~cm}$ : Highly phyric with glomerocrysts of orthopyroxene, often strongly altered to pale/orange brown clays and pale green chlorite. Fine-grained groundmass of plagioclase microlites and tiny opaques in glassy matrix $(\sim 70 \%)$ now very pale olive-brown to green clay minerals.

$57 \mathrm{R}-4,7-13 \mathrm{~cm}$ : Highly phyric with glomerocrysts of orthopyroxene partly replaced by pale brown clay minerals. Fine-grained groundmass with plagioclase microlites and altered pyroxenes plus abundant patches of 
pale/orange brown clays after glass $(\sim 40 \%)$. Sample is locally brecciated, and cracks and irregular vesicles are filled with a pale brown zeolite $(\sim 10 \%)$ with occasional patches of orange-brown and green clay minerals. Fragments often show rims of fine grained quartz.

$58 \mathrm{R}-1,121-126 \mathrm{~cm}$ : Moderately orthopyroxene-clinopyroxene phyric rock, with pyroxene phenocrysts strongly altered to pale/dark brown clays. Fine-grained groundmass of plagioclase microlites, clinopyroxene, and opaques with pale/dark brown clay materials replacing glass matrix (70\%). Sample has irregular vesicles $(\sim 10 \%)$ and fractures partially infilled with zeolite and/or brownish clays.

$65 \mathrm{R}-1,25-32 \mathrm{~cm}$ : Sparsely clinopyroxene phyric rock. Fine-grained crystalline groundmass of plagioclase laths, equant pyroxene, and opaque grains, with dark green-brown clays and chlorite replacing glass matrix $(\sim 40 \%)$. Minor interstitial calcite $(\sim 5 \%)$. 